\title{
THE 2012 GENERAL ELECTIONS IN LESOTHO A step towards the consolidation of democracy
}

\section{Tlohang W Letsie}

\begin{abstract}
Tlohang Letsie is a lecturer in the Department of Political and Administrative Studies of the National University of Lesotho e-mail: tlohang@yahoo.com
\end{abstract}

\begin{abstract}
The May 2012 general elections in Lesotho were held in the best political climate since democracy returned to the country in 1993. Even the minor disputes that surfaced were resolved speedily before they could graduate into serious election-related conflict. The elections were historic in that the results were not disputed. In addition, for the first time in the country's history the elections failed to produce a clear winner, hence the formation of a coalition government. The elections also resulted in a change of leadership, bringing to an end Pakalitha Mosisili's 14-year rule. The article contends that the peaceful conduct of the elections was the result of the amendments made to the country's electoral laws and the preparedness of the Independent Electoral Commission. It goes further to show how the Democratic Congress, the party with a relative majority of parliamentary seats, came to be omitted from the coalition government and was relegated to the opposition. All these, the article argues, are positive developments in the country's move towards democratic consolidation.
\end{abstract}

\section{INTRODUCTION}

On Saturday 26 May 2012 the people of Lesotho went to the polls to vote for the government of their choice. The May 2012 elections were the fourth since the country's return to democracy in 1993. This return followed 23 years of authoritarian rule, 16 of one-party rule and seven of military dictatorship. The other three polls, held in 1998, 2002, and 2007, were all disputed in one way or another.

In 1998 three opposition parties, namely, the Basotho National Party (BNP), Basutoland Congress Party (BCP) and Marematlou Freedom Party (MFP) refused to recognise the government of the Lesotho Congress for Democracy (LCD) 
because, they alleged, it had won the elections fraudulently (Mothibe 1999). Although it eventually took its seats in Parliament after the 2002 elections, the BNP initially rejected the results, alleging that there had been irregularities. In 2007 the MFP went to the High Court to challenge the final allocation of seats, arguing that the LCD/National Independent Party (NIP) alliance had received 20 more seats than it deserved (Elklit 2008, p 16).

Unlike on previous occasions no serious concerns were aired about the way the May 2012 elections were run. After the final allocation of seats it became clear that no party had won enough to form a government. As a result, for the first time in its electoral history Lesotho had a hung Parliament and the parties were compelled to negotiate with one another in order to form a coalition government.

When the negotiations and horse trading involved in coalition formations were over it emerged that despite having a relative majority of 48 seats in a 120-seat Parliament the incumbent party, the Democratic Congress (DC), had failed to persuade other parties to join a coalition and had, as a result, been relegated to the opposition.

In this article, which gives an overview of the 2012 elections, the elections are analysed within the democratic framework that uses election outcomes as a measure of democracy. This framework not only considers elections to be a prerequisite for democracy, it also regards acceptance of election results by all stakeholders as a step towards democratic consolidation. On this basis the article argues that Lesotho's 2012 elections were a positive step on the country's path to consolidating democracy. The four main sections of the article discuss the relationship between elections and democracy, the pre-election period, polling and election results and the formation of the coalition government.

\section{ELECTIONS AND DEMOCRACY}

Simply defined, elections are the process through which citizens vote for candidates wishing to take up seats in a parliament. It is important to note that contrary to many views elections consist of far more than merely the voting process, they are a multi-phased process stretching over a long period. Among the many stages of the electoral process are the registration of voters, nomination of candidates, campaigning, polling and the announcement of results.

Elections as a process are premised on the liberal democratic theories of representation that appreciate the need for citizens to be represented by an elected few in public decision-making. Elections have become a common feature of modern states because huge populations and vast geographical boundaries make it difficult for citizens to participate directly in public affairs. Lesotho is no exception in this regard. Commenting on elections, Axford \& Rosamond (1997, 
p 132) state that 'for the citizens, elections provide a particularly low-cost method of participating in the political process'.

Elections are generally regarded as a precondition for the process of democratisation. For Bratton \& Van de Walle (1997, p 194) 'a transition to democracy can be said to have occurred only when a regime has been installed on the basis of a competitive election, freely and fairly conducted within a matrix of civil liberties, with results accepted by all participants'. Using this argument it would be easy to conclude there had, prior to May 2012, not been any serious 'transition to democracy' in Lesotho. Opposition parties have, on a number of occasions in the past, complained that elections were not 'free and fair' and have, as a result, rejected the results.

Highlighting the importance of elections, Matlosa (2003, p 98) argues that they are intended to ensure the deepening and consolidation of democratic governance and political stability. Consolidating democracy, according to Smith (2003, p 259), 'entails strengthening democratic institutions, extending democratic processes and preventing authoritarian reversals'.

Elections perform a number of functions within political systems. Among other things they offer citizens a means of choosing representatives to participate on their behalf where direct participation is not feasible. Furthermore, they give governments legitimacy. Governments installed through elections normally get more recognition, both domestically and internationally, than their unelected counterparts. Most importantly, elections serve as a mechanism for changing governments, or extending or renewing the mandate of incumbent regimes (Kapa 2003; Helgesen 2008).

Because they are an integral feature of liberal democracies, elections are considered to be a panacea for conflict and instability. In Lesotho, however, ever since the pre-independence election in 1965, elections have triggered numerous conflicts. These reached a peak when, in 1998, they nearly plunged the country into civil war after the BNP, BCP and MFP rejected the LCD's victory, labelling it fraudulent. Order was only restored after military intervention by South Africa and Botswana. Opposition parties' rejection of election results and the resultant political instability have undermined the very process of democratisation in Lesotho. The May 2012 elections, however, differed from their predecessors in that all stakeholders accepted the results and the fact that the transfer of power from the incumbent DC to the new coalition government took place peacefully.

\section{BUILD UP TO POLLING DAY}

This section discusses the events that unfolded prior to Saturday 26 May 2012. It examines the efforts made by the country's Independent Electoral Commission 
(IEC) to prepare for the elections. It also discusses some of the amendments made to the country's electoral laws and views the activities of the political parties prior to polling day.

\section{The IEC's preparations}

In an effort to deliver acceptable and credible elections the IEC took some innovative steps including outsourcing civic and voter education and establishing a monitoring panel.

\section{Outsourcing of voter education}

In order to educate voters about their rights and about voting procedures ahead of the elections, the IEC renewed the partnership it had entered into with the Lesotho Council of Non-governmental Organizations (LCN) prior to the 2011 local government elections. In terms of this partnership, the $\mathrm{LCN}$ was to spearhead the civic and voter education campaign ahead of the elections. According to the IEC's Director of Elections, Mphasa Mokhochane, the main objective of the partnership was to fight the voter apathy that had characterised previous elections (Lesotho Times 28 April 2011, p 4). The opposition parties had earlier complained that the IEC lacked the capacity to provide adequate civic and voter education. The LCN engaged temporary staff, consisting mainly of college graduates, and distributed them among the country's 80 electoral constituencies. The delegation of civic and voter education to the $\mathrm{LCN}$ was welcomed by all political parties and there were no objections to the manner in which the LCN conducted this education.

\section{Monitoring panel}

The IEC also established a panel to monitor the use of public facilities by politicians ahead of the elections. The five-member panel comprised high calibre persons drawn from civil society organisations. The panel was established in response to complaints from opposition parties in previous elections that incumbent parties contested elections from an advantaged position in that they used state resources such as media and vehicles during their campaigns.

The creation of the monitoring panel was one of the rare steps taken by the IEC to be commended by opposition parties. In response to its establishment the leader of the All Basotho Convention (ABC), Tom Thabane, said:

this step by the IEC is a very commendable one that comes as a result of the consultation they had with us ... The 2007 general elections were characterized by rampant abuse of state resources; there was so much misuse of government transport by Ministers and government officers. 
As a result, the May 2012 polls were not characterised by any serious complaints about the ruling party's use of state resources during the electoral process.

\section{Electoral law reforms}

One of the most important steps taken by the country in preparation for the 2012 elections was the repeal of the National Assembly Elections Order 1992 and its replacement with the National Assembly Elections Act 2011. One of the notable reforms contained in the new Act is s55, which amends the format of the country's mixed member proportional (MMP) model from 'two ballots, two votes' to 'one ballot, two votes'. The section states that 'during general elections, constituency votes shall be counted both for the candidate and be converted into party votes'.

An electoral model is a very important element of elections. Heine (2006, p 82 ), for instance, writes that 'the type of electoral system to be set up is another critical challenge faced during transitions and one whose impact on the stability and continuity of the newly emerging democracy is by no means minor'. It was, therefore, important for the country to revisit its electoral system to ensure that it promotes political stability. As Nohlen (2001), cited in Heine (2006, p 82), notes, 'electoral systems in today's world are supposed to satisfy a number of criteria that include amongst the many, representativity [sic] - a balanced correlation between the number of allocated seats and the various social and political forces existing in the country at large'.

Another criterion for assessing the effectiveness of an electoral system is its ability to enable a number of political parties to be represented in Parliament.

The old 'two ballots, two votes' format of the Lesotho electoral system had proved to be problematic, contributing immensely to the political instability that characterised the post-2007 elections. The big parties, the ABC and the LCD, had taken advantage of it in 2007, adulterating the model by forming alliances (the ABC with the smaller Lesotho Workers Party - LWP and the LCD with the National Independent Party - NIP) in order to benefit from the compensatory seats allocated in line with the proportional representation (PR) aspect of the model.

Matlosa (2008) notes that after entering an alliance with the NIP in 2007 the LCD received 21 compensatory seats when it was entitled to only one seat. This allocation became a hotly contested issue for the rest of the Lesotho's seventh Parliament, from 2007 to 2012. With the law now stating specifically that constituency votes must also be converted into party seats, there was no longer a need for such controversial alliances prior to the 2012 elections.

Another improvement in the country's electoral law related to campaign funding. According to the new law, all parties registered with the IEC were, from 2012, entitled to funding from the Consolidated Fund for the purpose of 
campaigning and paying party agents. Prior to the 2012 elections parties received paltry allowances from the commission. In the 2007 general elections, for instance, the subvention was M450 (equivalent to South African R450) per registered candidate. Clarifying the formula to be used in the new allocation of the funds, s 70(5) of the Act states that:

(a) in respect of a political party which participated in the last elections, the funding shall be based on the number of votes gained in the last elections on condition that the votes gained were not less than the threshold required for registration with the Commission;

(b) in respect of a political party registered with the Commission which did not participate in the last elections, the funding shall be based on the threshold requirement for registration with the Commission.

This funding contributed to ensuring the effectiveness of the model, as it helped the parties canvass for support and increase their chances of being represented in Parliament. The IEC budgeted M2.7-million for campaign funding. According to the IEC, the highest amount went to the NIP, a small party that had benefited from an electoral alliance with the larger, then-ruling LCD prior to the 2007 elections. According to this arrangement, members of the LCD had voted for NIP on the PR ballot. Because of this, despite being a very small party, the

NIP got the biggest cheque of M800 000 for having 'won' 229602 votes in 2007 elections. The smallest cheques amounted to M1 742 each and went to Sefate Social Democracy (SSD) that registered 500 votes in the 2007 general election, and to all newly registered parties.

Lesotho Times 2 February 2012, p 7

Furthermore, in order to ensure representivity, s 47(a) provided for gender balance in the party lists submitted to the IEC. The lists must include equal numbers of women and men and, the section states, 'have to arrange candidates in order of preference from top to bottom, with a female or male candidate immediately followed by a candidate of the opposite sex'.

\section{Political parties}

The three months leading to polling day were dominated by electoral hype. Lesotho's Constitution provides that elections must be held within 90 days of the dissolution of a Parliament. The hysteria began with the formation of the DC, a splinter party of the LCD, on 28 February, a few days before Parliament 
was dissolved, and the subsequent announcement by the king of the date of the election.

The DC was to become a very important factor in the election, both in terms of voting patterns and in the formation of the coalition government. It was formed by the disgruntled Lija-mollo (fire-eaters) faction under the leadership of the former LCD leader and the country's prime minister, Pakalitha Mosisili. The Lija-Mollo and Litima-Mollo (fire extinguishers) factions had, for a long time, been locked in a tussle over control of the LCD. Though he was a chairman of the party's national executive committee, Mosisisili had completely lost control of the Litima-Mollo-dominated organ, hence his departure from the party.

The formation of the DC and the party's immediate usurpation of state power generated considerable debate in the country. The speaker of Parliament, Ntlhoi Motsamai, controversially declared the party the new government on 28 February after 45 LCD MPs crossed the floor to join it.

It is worth mentioning that, apart from being the speaker of Parliament, Motsamai was an LCD MP who had been party to the plan to defect and form the DC. Under Lesotho law constituency MPs are permitted to cross the floor and join new parties. This is, however, not the case with PR MPs who lose their parliamentary seats. As a result of this law some known LCD members who had won their seats through the NIP's PR list could not cross the floor with other members despite having been involved in the plans to form the DC.

Opposition parties were not impressed by the process of declaring the DC, which had only 45 seats in a 120 -member Parliament, the new government. The party had not entered an arrangement with any other party to acquire the minimum of 61 seats for a party, or coalition of parties, to form a government, as stipulated in s 87(2) of the Constitution. The day after the DC was declared the government opposition MPs walked out of Parliament in protest as members of the DC - together with those of the NIP (the majority of whom were known LCD members who had entered Parliament in 2007on the NIP PR list) - passed a vote of confidence in Mosisili. The vote was an attempt to give the newly declared government some legitimacy. The opposition MPs complained that Motsamai had ignored them when they had tried to raise points of order in an attempt to argue that the National Assembly Standing Orders made no provision for a vote of confidence. The vote showed that Mosisili had the support of 63 members in a Parliament of 120 seats (Lesotho Times 1 March 2012, p 1).

Three opposition MPs, Lehlohonolo T'sehlana of the Senkatana Social Democratic Party (SSDP), Sello Maphalla of the LWP and Pitso Maisa of the ABC, filed an urgent application asking the High Court to declare the DC government unconstitutional, arguing that the way the speaker had handled the issue of floor crossing and the subsequent declaration of the DC as the new government was 
flawed and erroneous. This view was shared by the then-deputy speaker, Sephiri Motanyane, who indicated that:

There was no physical floor-crossing as stipulated in the regulations. But even if the $45 \mathrm{MPs}$ had physically crossed the floor from the LCD to the DC it was wrong for the Speaker to then declare the DC as new government because it did not have the majority and she [the speaker] does not have powers to do so. Only the King has the power to declare a government formed.

Lesotho Times 15 March 2012, p 2

The High Court dismissed an application to have the DC government declared illegal on the grounds that it was not urgent (Sunday Express 11 March 2012, p 4).

In a similar fashion to what happened in 1997 after the LCD had relegated the $\mathrm{BCP}$ to opposition status, as polling day came closer the political atmosphere became polluted and there was a growing tension between the DC and the opposition parties, particularly the LCD. The tension became visible, not only among the leaders of the political parties but among ordinary members.

Supporters of different political parties were heard on local media, particularly the privately-owned media, condemning the DC and calling for opposition parties to vote for 'change' (the ousting of the DC). The unity among opposition parties became most vivid on Sunday 20 May, the day of the parties' last campaign rallies. Clad in their parties' regalia, members of the three main opposition parties, the ABC, the BNP and the LCD, were seen at rallies of the three parties in Maseru. However, no one in the colours of any of the three parties was seen at the DC rally. Similarly, DC supporters were nowhere to be seen at the other three parties' rallies.

To people familiar with Lesotho's politics these signs of unity among opposition parties were strange, as, prior to the formation of the $\mathrm{DC}$, the $\mathrm{ABC}$ and BNP did not see eye to eye with the LCD. These developments indicated clearly that the controversial relegation of the LCD to the status of opposition won the party sympathy from other opposition parties while at the same time widening the rift between itself and the DC. These developments later became vital factors in the election outcome and the formation of the coalition government, as becomes evident in the following sections.

\section{Party campaigns}

Following the announcement of the date of the election political parties began canvassing for support among voters. In total, 18 political parties and nine 
independent candidates registered to contest the election. Most party rallies were held at weekends. Some parties, most notably the DC, however, took their campaigning to another level, with door-to-door canvassing. As soon as the campaigning started, four parties - the ABC, BNP, DC and LCD - stood head and shoulders above the rest and, in terms of rally attendances, seemed to be the only serious contenders.

The local media played a crucial role in the party campaigns. From time to time political leaders appeared on local radio stations - national and private - to woo support. Party loyalists also took advantage of phone-in programmes to sell their parties to other listeners.

Over the years the national media have been accused of favouring the ruling party, in breach of s 61 of the Electoral Act, which dictates that public officers and authorities should give equal treatment to political parties registered with the IEC to enable them to conduct their campaigns freely. In an effort to level the playing fields prior to the 2012 elections, both national broadcasting agencies, TV Lesotho and Radio Lesotho, provided each of the parties contesting the elections with a one-hour slot, giving each a chance to be heard. It must, however, be stated that the move did not level the playing fields adequately as the incumbent DC continued to enjoy unlimited coverage under the pretext that its leaders were still in government and their activities had to be covered. Although this disparity was noted by opposition parties it did not become a serious issue.

\section{Violence at campaign rallies}

While campaigning was generally peaceful, there were sporadic incidents of disruption at DC rallies in the Maputsoe and Ha Thetsane industrial areas, where Mosisili was the main speaker. The disruptions were allegedly caused by factory workers suspected to be supporters of the ABC, the BNP and the LWP. Disgruntled workers were reported to have disrupted the DC's rallies in order to show their displeasure that Mosisili only came to them when he wanted their votes after neglecting them for more than 14 years (Public Eye 13 April 2012, p 4). Mosisili had, on numerous occasions, shunned textile industry workers, refusing to accept their petitions over low salaries and poor working conditions. While at Maputsoe Mosisili was merely heckled, violence broke out at Ha Thetsane and at least 10 people were injured and the windows of numerous vehicles were smashed (Sunday Express 22 April 2012, p 6).

At the Ha Thetsane rally Mosisili urged his supporters to retaliate whenever their rallies were disrupted, a call that was described as irresponsible by many analysts, who claimed it incited even more violence. The army, in the meantime, issued a strong warning following the disruptions and subsequent violence 
at the DC's rallies, threatening to hit perpetrators of violence 'very hard' and warning that such people were 'challenging the Lesotho Defence Force (LDF)'s capability to maintain law and order' (Sunday Express 22 April 2012, p 2). The army's warning was condemned by opposition parties as being biased in favour of Mosisili and his new party as the same army was accused of remaining silent while many Basotho - including prominent opposition politicians - were being attacked at an alarming rate. Among the politicians who were attacked were $\mathrm{ABC}$ MP Clement Machakela, the former minister of labour, who was murdered in his home in Sekamaneng, outside Maseru, on 19 March, and the party's chairman and MP, MolobeliSoulo, who escaped death by a whisker when he was shot and injured by unknown gunmen at his Lithoteng home in Maseru on 25 February (Lesotho Times 1 March 2012, p 2). No arrests have been made in connection with the two attacks.

The army's warning was described by some sectors of society as premature as the police had not claimed to be incapable of dealing with such acts. This view was shared by Nobel Peace laureate Archbishop Desmond Tutu, who urged the army to stay in its barracks until the rightful authority (the police) called on them (Sunday Express 22 April 2012, p 4). Tutu was speaking at a prayer session organised by the Christian Council of Lesotho and the United Nations Development Programme Lesotho to appeal for political tolerance during the election. Tutu reminded the LDF that 'the army was meant to be a people's army to defend the people, not a tool of unscrupulous politicians' (Sunday Express 22 April 2012, p 4).

Disturbances and violence prior to polling day were a new occurrence in Lesotho politics. In the past, violent conflict has manifested during the post-voting period. It was important, therefore, that the trend be stopped. However, the involvement of the army at that early stage could not be justified. Concern about the army's involvement was expressed in workshops organised both by local NGOs and by international election observer missions. The feared intimidation by the army of members of opposition parties did not, however materialise. From a few days prior to polling day to days after the official handover of the reins by the outgoing prime minister the uniformed members of the army were confined to their barracks.

\section{Election manifestos}

Generally, most of the party manifestos were similar, reflecting neither serious ideological nor issue differences. The manifestos of the four main contenders leaned towards social democracy, favouring a balance between the market and the state. For instance, all parties promised that their governments would work with the private sector to improve the economy and create job opportunities, 
stimulate agriculture to ensure food security and improve all aspects of the quality of life of the people.

Despite their general uniformity, the parties differed over some specific issues. The BNP promised to review the powers of the king in ensuring good governance in the country. The party also promised to hand back to Basotho privatised state-owned enterprises, as well as to hold a referendum on Land Act 2010, which allows foreigners to own land in Lesotho. The DC promised to review inheritance laws in line with international conventions the country has signed. The LCD, on the other hand, promised to enact a law limiting the prime minister's terms of office to a maximum of 10 years - two parliamentary terms. Currently, the term is not fixed. Furthermore, the party promised to review the issue of dual citizenship, which is outlawed by the current Constitution.

\section{THE MAY 2012 GENERAL ELECTION AND THE FORMATION OF THE COALITION GOVERNMENT}

Following weeks of intensive campaigning, the people of Lesotho went to the polls on Saturday 26 May 2012. As stated above, attendances at party rallies suggested that the serious contest would be among the $\mathrm{ABC}$, the $\mathrm{BNP}$, the $\mathrm{DC}$ and the LCD. On this basis analysts and some party leaders, notably Advocate Lekhetho Rakuoane of the Popular Front for Democracy (PFD), warned the country to brace itself for a coalition government. The four-party contest was a new occurrence in the country's electoral history. Pre-electoral campaigns have, in the past, been two-party races - in 1998 between the BCP and the BNP, in 2002 between the LCD and the BNP and in 2007 between the LCD and the ABC.

Numerous groups, both local and international, observed the elections. Most notable among these groups were the Commonwealth Election Observer group, headed by former Malawi president BakiliMuluzi, and the Southern African Development Community (SADC) Electoral Observer Mission, led by South Africa's Deputy Minister of International Relations and Co-operation, Ebrahim Ismail Ebrahim. Also present was a mission from the Electoral Institute for Sustainable Democracy in Africa (EISA), headed by former Zambian president Rupiah Banda. Apart from a few minor problems at some polling stations, voting went smoothly, as attested to by the reports of the various observer missions and the lack of complaints from political parties.

Election results, announced from the morning of Sunday 27 May, indicated that the predictions had been correct. Of the 80 constituency seats contested, the DC won 41, the ABC 26 and the LCD 12. Contrary to the predictions of many analysts, the dark horse, the PFD, won one constituency while one of the favourites, the BNP, failed to win a seat (IEC 2012). 
All parties accepted the results. As noted above, Bratton \& Van De Walle (1997, p 194) argue that acceptance of election results is a positive development in democratic transition. This rare, yet positive occurrence proved to be a milestone in a country in which the results of all elections held since independence had been contested, leading, in some cases, to bloody conflicts between losers and winners.

In 1970 BNP leader Leabua Jonathan annulled the election when it became apparent that his party was losing to the BCP. Election results were also contested in 1993, when, following the humiliating loss to its bitter rival, the BCP, the BNP claimed 'the elections were rigged and challenged the results in the courts of law' (Kadima 1999, p 76). In that election, held according to the first-past-the-post system, the BCP won all 65 constituencies, with an overall $75 \%$ of the votes cast (Mahao 1997). This meant the party held $100 \%$ of parliamentary seats. Attempts to reverse the results through the courts failed and the BNP engaged in protests that threatened the country's political stability and led to the loss of life.

There was another dispute over election results in 1998, when three opposition parties - the BCP, the BNP and the MFP - refused to recognise the LCD government because, they alleged, it had won the elections fraudulently (Mothibe 1999). The newly formed LCD had won 78 of the 79 constituencies contested. The three parties challenged the authenticity of the election results in the courts and, when their challenges failed, organised a march to the royal palace on 4 August. After handing over their petition the protesters refused to leave the palace gates. Instead, they organised a sit in that was to last more than a month until it was dispersed by the South African National Defence Force on the morning of 22 September.

Lesotho held another general election in 2002 after the country had adopted the MMP electoral model as a consequence of the 1998 electoral conflict. The LCD once again won the election overwhelmingly, this time taking 77 of the 78 constituencies contested, with a single seat going to the Lesotho People's Congress (LPC). FPTP elections failed to take place in two constituencies because of the deaths of some candidates. Southall (2003, p 288) writes that 'when the parliamentary seats were finally allocated the ruling LCD was barred from securing any seat from the PR wing of the electoral model because it already had 77 (or 65\%) of the total number of 118 (constituency + PR) seats being competed for on the election day (or 12 more seats than the party's proportional entitlement)'. The remaining 40 PR seats were shared among nine opposition parties.

Elklit $(2002, \mathrm{p} 8)$ notes that despite the fact that the quota of votes needed for a party to gain a PR seat was 5910 one small party, the National Progressive Party (NPP) managed to get a seat by virtue of having the highest remainder - 3985 . The BNP once again rejected the election results. Its leader, Major General Metsing Lekhanya, made 'generalized complaints about electoral malpractice and alleged 
curious statistical patterns in the votes' (Southall 2003, p 290). The BNP later took up its position as the main opposition, with 21 seats. The election was seen by many observers as a milestone as, for the first time in its history, Lesotho had an inclusive Parliament with 10 political parties represented (Kabemba 2006, p 21).

Further elections were held in February 2007, following the formation of the ABC by 17 disgruntled LCD MPs and one independent candidate. This left the LCD with just 61 seats, a one-seat majority. It was this precarious situation that, according to Likoti (2008), persuaded Prime Minister Mosisili, leader of the LCD, to act swiftly and advise the king to dissolve Parliament and call for new elections. In an effort to strengthen their chances of winning the elections two contenders, the $\mathrm{LCD}$ and the $\mathrm{ABC}$, formed electoral alliances with smaller parties, the LCD with the NIP and the ABC with the LWP. The alliances were designed to allow the bigger partners access to the PR compensatory seats that, in terms of the MMP system, are rarely available to parties that win constituencies. The allocation of PR seats that resulted from this arrangement was to become a post-election issue on which new conflict was to centre.

According to the election results that were announced, the LCD won 61 constituencies, the ABC 17, and the Lesotho People's Congress (LPC) one (IEC 2007). Voting for one FPTP seat had not taken place in Thaba-Putsoa \# 39 constituency because of the death of one of the candidates. The final allocation of seats was 82 for the LCD/ NIP alliance and 27 for the ABC/LWP, with the rest of the seats divided among seven smaller parties (IEC 2007).

The allocation of seats to the two alliances was hotly disputed by the opposition parties, who argued that if the model had been applied appropriately the LCD/NIP alliance would have received a total of 62 seats as against 82 . The $\mathrm{ABC} / \mathrm{LWP}$ alliance, on the other hand, would have received 29 seats as opposed to its 27. Other smaller parties 'would have increased their parliamentary seats through the PR component and one other small party, the New Lesotho Freedom Party (NLFP), which was not represented in Parliament would have at least won one seat' (Matlosa 2008, p 41).

The adulteration of the electoral model through the formation of these controversial alliances has been described by Jørgen Elklit, a professor of Political Science who was appointed international advisor to the Lesotho IEC prior to the introduction of the MMP system in 2002, as an abuse of the system (Elklit 2008). Protests over the allocation of seats took many forms, including court cases and work boycotts organised by civic organisations sympathetic to the opposition parties. The conflict even attracted the attention of SADC, which assigned the former president of Botswana, Sir Ketumile Masire, to mediate. Masire later abandoned his mediation, citing lack of cooperation from the ruling LCD. 
This history of non-acceptance of election results shows why the fact that the 2012 results were accepted was a cause for celebration, marking, as it did, a departure from what had become the norm. The following sections are concerned with the discussion of allocation of parliamentary seats in the eighth Parliament of Lesotho and the dynamics of coalition government in the country.

\section{HUNG PARLIAMENT AND THE FORMATION OF THE COALITION GOVERNMENT}

Lesotho's National Assembly consists of 120 seats. Of these, 80 constituency seats are filled through the FPTP element of the country's MMP model and the other 40 are party seats, determined by PR. Table 1 shows the final allocation of seats after the 2012 general election.

Table 1

\section{Final Seat Allocation in Lesotho's Eighth Parliament}

\begin{tabular}{|c|c|c|c|c|c|c|}
\hline Party & $\begin{array}{c}\text { Total } \\
\text { votes } \\
\text { received }\end{array}$ & $\begin{array}{c}\text { Party's } \\
\text { proportion } \\
\text { of votes }\end{array}$ & $\begin{array}{c}\text { Allocation } \\
\text { based on } \\
\text { proportion }\end{array}$ & $\begin{array}{c}\text { Constituency } \\
\text { seats won by } \\
\text { the party }\end{array}$ & $\begin{array}{c}\text { Provisional } \\
\text { allocation of } \\
\text { PR seats }\end{array}$ & $\begin{array}{c}\text { Total } \\
\text { number of } \\
\text { seats } \\
\end{array}$ \\
\hline $\mathrm{ABC}$ & 138917 & 30.21 & 30 & 26 & 4 & 30 \\
\hline BBDP & 2440 & 0.53 & 0 & 0 & 1 & 1 \\
\hline $\mathrm{BCP}$ & 2531 & 0.55 & 1 & 0 & 1 & 1 \\
\hline BDNP & 3433 & 0.75 & 0 & 0 & 1 & 1 \\
\hline BNP & 23788 & 5.17 & 5 & 0 & 5 & 5 \\
\hline $\mathrm{DC}$ & 218366 & 47.49 & 47 & 41 & 7 & 48 \\
\hline LCD & 121076 & 26.33 & 26 & 12 & 14 & 26 \\
\hline LPC & 5021 & 1.09 & 1 & 0 & 1 & 1 \\
\hline LWP & 2408 & 0.52 & 0 & 0 & 1 & 1 \\
\hline MFP & 3300 & 0.72 & 0 & 0 & 1 & 1 \\
\hline NIP & 6880 & 1.50 & 1 & 0 & 2 & 2 \\
\hline PFD & 11166 & 2.43 & 2 & 1 & 2 & 3 \\
\hline Others & 12400 & & 0 & 0 & 0 & 0 \\
\hline Total & 551726 & & & 80 & 40 & 120 \\
\hline
\end{tabular}

Source: IEC 2012

The table shows that 12 political parties are represented, one more than the number represented in the previous Parliament. The implication of the allocation of seats, 
as shown in the table, was that for the first time the country had a hung parliament, a situation in which no political party (or block of allied parties) has an absolute majority, which, in the case of Lesotho, is a minimum of 61 seats.

Consequently, the parties were compelled to negotiate among themselves with a view to forming a coalition government. On the basis of the allocation of seats it would appear that the DC was best placed to lead the resultant coalition. By virtue of having a majority of 48 seats the party needed just 13 to reach the required 61 needed for a party, or a coalition, to form a government in terms of s 87(2) of the Constitution.

This was, however, not to be the case. With the DC and the ABC having the two highest numbers of seats, the LCD became the 'kingmaker', holding the key to a coalition government. Unless the two leading parties decided to work together, which was very unlikely in view of the antagonistic relationship between both their leaders and their members, neither could form a government without the LCD. For this reason both parties approached the LCD and the ABC successfully persuaded it to join it in a three-party coalition, which included the BNP, another sworn rival of the DC.

The DC's failure to attract allies into a coalition government meant the party was relegated to the opposition benches, marking the end, not only of DC rule but also of the 14-year reign as prime minister of Pakalitha Mosisili, who had been handpicked by the former leader of the LCD, the charismatic Ntsu Mokhehle, in 1997.

Had the DC succeeded in forming a government Mosisili would have achieved another five years as head of government, at the end of which he would have been in office for 19 years, making him one of the longest-serving heads of government in Africa. This is the trend the continent is trying to move away from as it has proved to be one of the catalysts for the creation of dictatorships.

It was always going to be difficult for the DC to court the LCD in view of the unceremonious manner in which it had broken away just three months before the May 2012 election. It was, therefore, no surprise that the LCD opted for coalition with the $\mathrm{ABC}$. A few days before polling day LCD leader Metsing had made it clear that his party, 'as a matter of principle, and not hatred, would never go into a coalition with the DC'. He maintained that ' ... engaging the DC clandestinely would be an insult and a betrayal of voters who are crying for change. After all they [the DC] have made it very clear at their rallies that they would not put up with a coalition government' (Lesotho Times 24 May 2012).

As Metsing's statement suggests, the omission of the DC from the coalition government can largely be blamed on the party itself, and particularly on Mosisili. Even after all the indicators had pointed to the fact that there was likely to be a coalition government after the elections Mosisili remained in denial, insisting that 
his DC would win enough seats to form a government. He went to the extent of calling analysts who predicted a coalition government 'false prophets'.

In view of the above it is clear that the country's new coalition government did not emerge from any ideological considerations, it was largely determined by the desire of the electorate to bring about change.

The change itself was premised on at least two considerations. Firstly, the electorate wanted a change of government as the 14 years of Mosisili's rule had failed to rid the country of social ills such as poverty, unemployment, HIV / Aids, crime and corruption, to name just a few. Some of these failures have been acknowledged by Mosisili himself. Handing over the reins of government to Prime Minister Thabane on 8 June 2012, Mosisili admitted that his government had failed to deal with a number of problems, most notably corruption within its own structures. Although Mosisili did not mention it specifically, HIV / Aids remains one of the most burning problems the ABC-led coalition has inherited. As at July 2012 the prevalence rate in the country was about 24\% (Index Mundi 2012).

The electorate's desire to replace Mosisili is illustrated by the fact that the party failed to win a single constituency in the capital, Maseru, and other lowlands urban centres. The ABC won all the constituencies in Maseru as well as those in the Teya-teyaneng and Mafeteng town centres. Hlotse and Maputsoe (both in Leribe) went to the LCD. History has shown that urban dwellers are always the first to be hit by failures of government and consequently become the first to call for change by voting for opposition parties. This was evident when, in Zimbabwe, the Zimbabwe African National Union-Patriotic Front lost urban constituencies to the Movement for Democratic Change in 2008.

There is also a possibility that the DC's loss was the result of the electorate's desire to 'punish' Mosisili and the party for the 'wrongs' committed during the party's formation in February. To ensure that Mosisili and the DC were removed from power some members of the business community in Leribe, the home district of the LCD leader, Mothejoa Metsing, promoted what they called the Tona-kholoeaBochabela (Prime Minister from the East) campaign.

The ten districts of Lesotho are divided into three main administrative divisions, the South, the Central and the North. Though the Leribe district forms part of the North, it is located to the east of Maseru and is usually referred to as Bochabela (East).

Mosisili comes from the southern district of Qacha's Neck. Through the Tona-kholoeaBochabela campaign, the Leribe community called for voters in the district, irrespective of their party affiliation, to join hands and vote for the LCD. The campaign probably explains how the LCD managed to win nine of the district's 13 constituencies. The DC won just two, with the remaining two going to the $\mathrm{ABC}$. 
The eighth Parliament was officially opened and MPs sworn in on Wednesday 6 June. With the amendment of the electoral law to force parties to include equal numbers of women and men on their PR lists, there was always going to be a need to assess the gender balance in the new National Assembly. Overall, there are 31 women in the eighth Parliament, an increase of only two from the number in the previous National Assembly. A deeper analysis of the composition of the candidates shows that the amendment has had a great impact on gender balance - there is a strong possibility that without the amendment the number of women in the National Assembly would have fallen. Of the 80 constituency seats, only $13(16.3 \%)$ were won by women. However, there was a huge difference in the PR seats, where women received 18 ( $45 \%$ of the 40 available).

Thomas Thabane, leader of the main party in the coalition, the ABC, was sworn in as the country's new prime minister on Friday 8 June at a ceremony in the Setsoto national stadium graced by the attendance of their majesties King Letsie III and Queen 'Masenate. At the ceremony Mosisili handed over the reins of power to Thabane. The peaceful transfer of power from the DC to the ABC/BNP/LCD coalition was an historic event and a positive development in the consolidation of democracy in the country. Never before had an outgoing prime minister handed over power to his successor. All elections since the return to democratic rule in 1993 had seen the incumbent prime minister returned to power.

On 15 June Thabane announced his 30-member Cabinet, consisting of 23 ministers and seven deputy ministers. As expected, the Cabinet was made up of ministers drawn from all three coalition parties. The $A B C$ received 11 ministerial posts, the LCD 10 and the BNP two. The LCD received four of the most strategic ministries - finance, foreign affairs, public works and education. The $A B C$ received defence, police and national security, justice and mining, while the BNP bagged home affairs.

\section{CONCLUSION}

The enviable atmosphere that surrounded the 2012 general elections and the peaceful transition have brought hope to the people of Lesotho that the democracy that has eluded the country in the past is starting to mature.

The peaceful atmosphere was made possible by the thorough preparations made by the country's IEC and the enactment of the new electoral laws. The number of parties represented in Parliament has increased from 11 to 12, a positive step as it enables more views to be represented. For the first time in the country's electoral history there have been no serious election-related disputes.

The elections were also historic in that they produced no outright winner and, as a result, gave birth to the first coalition government in the country's history. 
Furthermore, the election brought to an end Mosisili's 14-year rule. Had his party won the elections or been part of the coalition government Mosisili would have ruled for another term and, in the process, become one of the longest-serving heads of governments in Africa, a trend that the continent is trying to move away from.

\section{- REFERENCES -}

\section{Publications}

Axford, B \& B Rosamond. 1997. 'Political Participation'. In B Axford, G K Browning, R Huggins, B Rosamond \& J Turner. Politics: An Introduction. London: Routledge.

Bratton, M \& N van de Walle. 1997. Democratic Experiments in Africa: Regime Transitions in Comparative Perspective. Cambridge: Cambridge University Press.

Elklit, J. 2002. 'Lesotho 2002: Africa's first MMP elections'. Journal of African Elections 1(2).

Elklit, J. 2008. 'The 2007 General Election in Lesotho: Abuse of the MMP System?' Journal of African Elections 7(1).

Heine, J. 2006. 'Institutional engineering in new democracies'. In U J van Beek (ed). Democracy Under Construction. Pretoria: Van Schaik Publishers.

Helgesen, V. 2008.Elections: A Vehicle for Triggering or Tempering Conflict? IDEA.F:/ election and conflict. Available at: www.idea.int/news/editorial_feb08.cfm.

Index Mundi. 2012. Available at: www.indexmundi.com/lesotho/hiv_aids_adult_ prevelence_ratehtm/

Intelserv Lesotho. Talking points for Sir KetumileMasire, 9 July 2009. Available at: www.intelserv.co.ls/index.php?optio=com_content\&task=view

Kadima, D. 1999. 'The DRC and Lesotho Crises: Some Lessons for SADC'. Lesotho Social Sciences Review 5(1).

Kabemba, C. 2006. From Military Rule to Multiparty Democracy: Political Reforms and Challenges in Lesotho. Johannesburg: EISA.

Kapa, M A. 2003.'Secrecy and Transparency in Lesotho's General Elections'. African Security Review 12(14).

Likoti, F J. 2008. 'The 2007 General Election in Lesotho: The Application and the Challenges of the Electoral System'. African Studies Quarterly: The Online Journal for African Studies 10(4). Available at: www.africa.ufl.edu/asq/ internal / forthcoming/v10i4a3.htm

Mahao, N. 1997. 'The 1993 Election and the Challenges for the Development of Constitutionalism in Lesotho'. Lesotho Social Sciences Review 3(2).

Matlosa, K. 2003. 'Political Culture and Democratic Governance in Southern Africa'. African Journal of Political Science 8(1). 
Matlosa, K. 2008. 'The 2007 General Election in Lesotho: Managing the PostElection Conflict'. Journal of African Elections 7(1).

Mothibe, T. 1999. 'The Military and Democratization in Lesotho'. Lesotho Social Sciences Review 5(1).

Pule, N W. 2002. 'Politics since Independence'. In N Pule \& M Thabane (eds). Essays on Aspects of the Political Economy of Lesotho 1500-2000. Department of History, National University of Lesotho: Morija Printing Works

Smith, B C. 2003. Understanding Third World Politics: Theories of Political Change \& Development. New York: Palgrave Macmillan.

Southall, R. 2003. 'An Unlikely Success: South Africa and Lesotho's Election of 2002'. Journal of Modern African Studies 41(2).

Van de Walle, B. 2001. African Economies and the Politics of Permanent Crisis, 1979 - 1999. Cambridge: Cambridge University Press.

\section{Legislation}

Constitution of the Kingdom of Lesotho. 1993. Maseru: Lesotho Government Printers.

National Assembly Election Order, 1992: 2001 Amendment.

National Assembly Electoral Act, 2011

\section{Documents}

Independent Electoral Commission of Lesotho (IEC). 2007. Report: Lesotho National Assembly Election Results 2007.

IEC. 2012. Report: Lesotho National Assembly Elections Results 2012.

IEC. 2012. Lesotho National Assembly Elections Final Seat Allocation.

\section{Party manifestos 2012}

All Basotho Convention

Basotho National Party

Democratic Congress

Lesotho Congress for Democracy

\section{Newspapers}

Lesotho Times 28 April 282011

Lesotho Times 2 February 2012

Lesotho Times 1 March 2012

Lesotho Times 15 March 2012

Lesotho Times 24 May 2012

Public Eye 13 April 2007

Public Eye 20 April 2012

Sunday Express 22 April 2007

Sunday Express 11 March 2012 